\title{
Uncommon cause of adult onset cyanosis: single left ventricle
}

\author{
Harsh Agrawal, ${ }^{1}$ Jessica D Schaefer, ${ }^{2}$ Mohamed Teleb, ${ }^{1}$ Laura M Cashin ${ }^{1}$
}

${ }^{1}$ Department of Internal Medicine, Division of Cardiovascular Medicine, Texas Tech University, Paul L Foster School of Medicine, El Paso, Texas, USA

${ }^{2}$ School of Nursing, University of Colorado, Denver, Colorado, USA

\section{Correspondence to}

Harsh Agrawal,

harshagrawal@hotmail.com

Accepted 22 January 2017

\section{(a) CrossMark}

To cite: Agrawal $\mathrm{H}_{\text {, }}$ Schaefer JD, Teleb M, et al. BMJ Case Rep Published online: [please include Day Month Year] doi:10.1136/ bcr-2016-219166

\section{DESCRIPTION}

A native American man aged 41 years presented with progressive shortness of breath and discolouration of his lips. Physical examination was significant for central cyanosis and clubbing. Given his cardiac history, echocardiogram and cardiac MRI were ordered to look at the cardiac anatomy and physiology. MRI revealed that the patient has laevorotation of the heart with the cardiac apex pointing posterior to the left midaxillary line with double-inlet morphologic left ventricle (DILV), which was enlarged and hypertrophied. There was a hypoplastic right ventricle which lies superior and anterior to the morphologic left ventricle with large

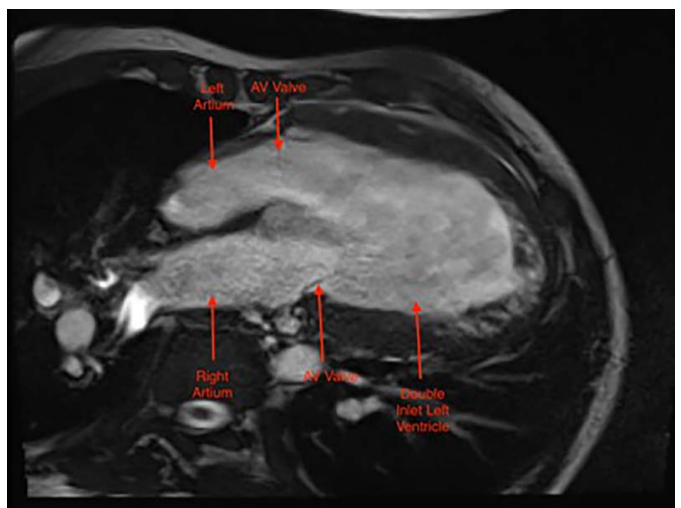

Figure 1 MRI of the heart double-inlet left ventricle (LV) with atrioventricular valves are inserted at the same level and draining into a common LV.



Figure 2 MRI showing the bulbo-ventricular foramen with ventricular septal defect providing systemic flow to the aorta and the pulmonary circulation with dilated pulmonary artery. There is complete mixing of systemic and venous circulation.

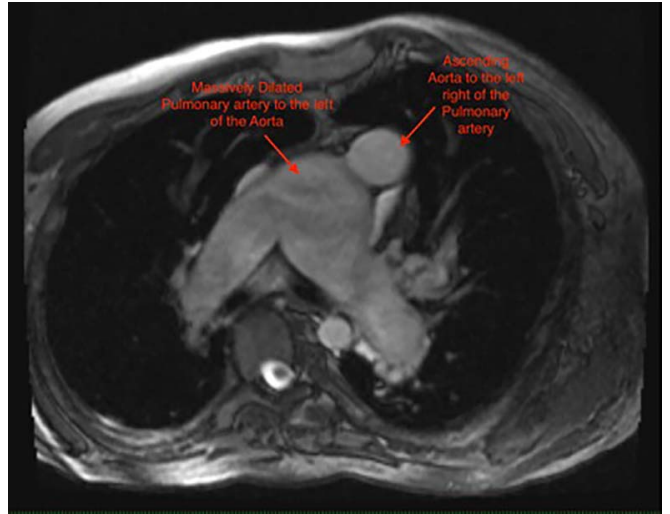

Figure 3 MRI showing the relationship of the great vessels consistent with $\mathrm{D}$-transposition of great arteries. Notice massive dilation of the pulmonary artery consistent with pulmonary hypertension.

ventricular septal defect. The aorta arises from the hypoplastic right ventricle and courses anterior and to the left of the pulmonary arteries (figures 1-3). There is no pulmonary stenosis or subpulmonary stenosis noted on transthoracic echocardiography, which makes this case even more unique given that is been shown to have a survival benefit in patients with DILV. MRI shows that he was born with DILV and D-transposition of the great vessels, which was never surgically corrected. This patient is truly remarkable, in that he has survived into his fourth decade of life without surgical intervention.

\section{Learning points}

- Adult onset cyanosis in this patient was due to Eisenmenger's syndrome.

- Cardiac transplantation is the only viable option for such patients.

- These patients should only be managed at specialised centres. In a retrospective review at Mayo Clinic, there was an annual death rate of $5 \%$.

Contributors HA, JDS, MT and LMC are responsible for study conception and design and analysis and interpretation of data. HA and JDS are responsible for acquisition of data and drafting of the manuscript. MT and LMC are responsible for critical revision.

Competing interests None declared.

Patient consent Obtained.

Provenance and peer review Not commissioned; externally peer reviewed.

\section{REFERENCE}

1 Poterucha JT, Anavekar NS, Egbe AC, et al. Survival and outcomes of patients with unoperated single ventricle. Heart 2016;102:216-22. 
Copyright 2017 BMJ Publishing Group. All rights reserved. For permission to reuse any of this content visit http://group.bmj.com/group/rights-licensing/permissions.

BMJ Case Report Fellows may re-use this article for personal use and teaching without any further permission.

Become a Fellow of BMJ Case Reports today and you can:

- Submit as many cases as you like

- Enjoy fast sympathetic peer review and rapid publication of accepted articles

- Access all the published articles

- Re-use any of the published material for personal use and teaching without further permission

For information on Institutional Fellowships contact consortiasales@bmjgroup.com

Visit casereports.bmj.com for more articles like this and to become a Fellow 